\title{
Happiness in Bangladesh: The Role of Religion and Connectedness
}

\author{
Joe Devine $^{1}$ (D) Timothy Hinks $^{2} \cdot$ Arif Naveed $^{3}$
}

Published online: 16 December 2017

(C) The Author(s) 2017. This article is an open access publication

\begin{abstract}
Research into the relation between religion and happiness offers inconclusive evidence. Religion seems to matter but it is not entirely clear how and why. Moreover much of the research to date is rooted in western experiences. This article analyzes primary data from Bangladesh to examine how religion figures in people's wellbeing and life chances. It identifies differences in reported happiness between the country's two largest religious populations: Muslims and Hindus. Our main argument is that the significance of religion is only really understood when considered alongside social, economic and political processes. The data and analysis make an important contribution to the limited knowledge we have of the relation between religion, political connectedness and happiness in non-western societies. It also highlights the need to incorporate more contextualizing analyses into our assessments of the relation between religion and happiness.
\end{abstract}

Keywords Religion $\cdot$ Happiness $\cdot$ Location $\cdot$ Social resources $\cdot$ Bangladesh

Joe Devine

j.devine@bath.ac.uk

Timothy Hinks

Timothy.Hinks@uwe.ac.uk

Arif Naveed

man48@cam.ac.uk

1 Department of Social and Policy Sciences, University of Bath, Claverton Down, Bath BA2 7AY, England, UK

2 Department of Accounting, Economics and Finance, University of West England, Bristol, BS16 1QY, England, UK

3 Faculty of Education, University of Cambridge, 184 Hills Road, Cambridge CB4 8PQ,

England, UK 


\section{Introduction}

\subsection{Religion and Wellbeing}

Academic interest in the connection between religion and happiness has grown significantly over recent years, and produced an impressive body of scholarship. Many studies demonstrate a positive association between religion and happiness. The significance of this association should not be underestimated. For example Witter et al. (1985) reviewed 28 wellbeing studies and found that the majority reported a positive association between religion and subjective wellbeing. Moreover they found that religion accounted for $2-6 \%$ of the variation in subjective wellbeing. Ellison et al. (1989) went one step further arguing that the effect of religion on subjective wellbeing is as strong if not stronger than income. This finds some support in Luttmer's claim that religion is positively correlated with measures of subjective wellbeing even when demographic variables such as income, age and marital status are taken into account (Luttmer 2005).

In what ways then does religion make us happy? The evidence offered by the literature falls broadly into two categories, reflecting a distinction first introduced by Allport and Ross's (1967) pioneering work into religious orientation. According to Allport and Ross, people have intrinsic or extrinsic motivations in relation to religion. The latter sees religion as a means to achieve particular goals including non-religious ones while the former is autonomous and considers religion as an end in itself. Although this distinction is not without its critics (see Lavrič and Flere 2007), it has left its mark on research into religion and happiness. On the one hand therefore it is argued that religion enhances wellbeing because it offers access to support structures or enables individuals to cope with stress (Lim and Putnam 2010), or to adapt preferences or aspirations (Clark 2012). On the other hand, religion enhances wellbeing because it offers a sense of meaning and purpose, and acts as a moral compass in this as well as the 'after-life' (Greeley and Hout 2006). What is striking however is that we can find evidence of both intrinsic and extrinsic benefits of religion in all of the world's major religions including Islam (Sahraian et al. 2013), Hinduism (Ganga and Kutty 2013), Judaism (Levin 2014), Buddhism (Elliot 2014), and Christianity (Steiner et al. 2010). Although the effects of religion on wellbeing are generally reported as being positive, there are important counter observations. First, religion may also be a factor in producing negative wellbeing values. Ellis (1962) for example reports that excessive religion can produce depression and mental disorders. More recently, Mookerjee and Beron's cross country analysis of the relation between religion and happiness concluded that contexts with high levels of religious fractionalisation produce relatively lower levels of happiness (Mookerjee and Beron 2005). Second, much of the literature draws conclusions on the effects of religion from studies that focus entirely on individual level processes. As such the context is overlooked. Some recent work has warned of the dangers of this approach arguing that positive individual level effects disappear when contextualised with a country's overall level of religiosity (Eichhorn 2012). Third, it is important to acknowledge the bias in the literature towards religious experiences and contexts in the West with relatively little attention being paid to non-western contexts where the parameters of any discussion about religion and wellbeing may be radically different (Joshanloo 2013, 2014). Finally, most of the literature rests on an assumption about the direction of causality. Thus it is assumed that religion leads to happiness as opposed to happiness leading to religion. 


\subsection{Religion and Wellbeing in Bangladesh}

Our research focuses on the relation between religion and wellbeing in Bangladesh, and as such contributes to the nascent scholarship focusing specifically on wellbeing in countries of the Global South (Diener et al. 2013; Shams 2016). Bangladesh is a particularly appropriate location in which to examine wellbeing dynamics since it throws up a number of wellbeing puzzles which all reflect different aspects of the Easterlin paradox (Easterlin 1974). Thus in the 1990s, Bangladesh reported higher levels of happiness than many other countries, including the UK, where people enjoy significantly larger per capita incomes and access to a wider range of basic services and good (Worcester 1998). Since the 1990s, the country has made significant progress in reducing poverty and introducing socio-economic improvements (Devine and Wood 2017), and can be described as a global international development success story. Despite this however, levels of reported happiness seem to be declining (Asadullah and Chaudhury 2012). Improved living standards therefore seem to be having an impact upon the wellbeing expectations and demands of its citizens (Diener et al. 2013).

The early years of state formation in Bangladesh were anchored in a very clear commitment to secularism, and indeed early writings on religion, most notably Islam, emphasised its syncretic and malleable qualities (Uddin 2006). However since the early 1990s, a different expression of religion has emerged which has been described as neo-orthodox, militant, and extremist (Riaz 2004). These changes reflect deeper questions about what constitutes 'proper' Islam in Bangladesh and also what constitutes a 'Muslim democracy' (Devine and White 2013). The unresolved nature of these questions is etched visibly in the relations between the dominant Muslims and followers of other religions in the country. Muslims in Bangladesh constitute around $87 \%$ of the population. While the remaining $13 \%$ belong to a number of different religions, Hinduism is by far the largest minority religion in the country.

In Bangladesh religion is directly translated as dharma, a term which derives from the Sanskrit $d h r$ meaning to sustain, support or uphold (Mahony 1987). However dharma means more than just 'religion', at least as understood in the West. Etymologically, dharma refers to the 'proper cosmo-moral ordering' of things (Inden 1985). In this sense, everything that exists, animate or inanimate, has its dharma. Even religion has its own dharma. Second, the word dharma is used in everyday speech to ask about one's religion. So it is quite common in Bangladesh to ask: 'apnar dharma ki?', i.e. what is your religion?. The response to this question however reveals two things. First, it communicates a person's religious affiliation. Second, the declaration of a religious affiliation or identity provides important implicit information on which social groups you belong to and can interact with; what practical lifestyle choices you can or cannot make; what constitutes appropriate behaviour and conduct; what aspirations you might have; who you can marry, what food you can eat, and so forth (Kotalova 1993). Dharma therefore is as much about everyday practical choices and opportunities as it is about religious affiliation.

There is very little literature on the relation between religion and wellbeing in Bangladesh. The founding research projects which inform this paper, ${ }^{1}$ found statistically

\footnotetext{
1 There are two founding funded research projects: (a) the Wellbeing in Developing Countries programme (2002-2007) funded by the UK's Economic Social Research Council, and (b) the Religion and Development programme (2008-2010) funded by the UK's Department for International Development. Anonymous has since carried out follow up interviews with key informants repeated at least once per year over the 2010-2016 period.
} 
significant correlations between religion and happiness, especially among older respondents (Camfield et al. 2009). In more qualitative follow-up research, we identified a number of areas where the influence of religion on wellbeing comes to the fore including the structuring of community relations (Devine and White 2013), responsibilities, obligations and expectations around marriage, gender and intergenerational relations (White 2012), and the development of political culture and democracy (Basu et al. 2017).

Recently Asadullah and Chaudhury (2012) offer a very different argument. Analysing data from 2400 households across 12 districts in Bangladesh, the authors claim that neither religion nor gender had any significant impact on happiness. Instead they found that the influence of inter-personal relations and social trust on happiness was statistically significant. This opens up a new avenue into an equally under-researched area, i.e. trust. The only study on trust we could identify was Gupta et al's (2013) comparative analysis of the behaviour of Muslims and Hindus in Bangladesh and West Bengal in India. In the latter, Hindus constitute the majority group and Muslims the minority; whilst in the former, the opposite is true. In both sites, the authors found that identity based on status (i.e. being a member of the majority or minority group) rather than religion per se determined levels of trust and trustworthiness. We return to this finding in our Sect. 3 below.

Our research makes three important contributions. First, to the best of our knowledge, the findings presented here are the first to quantitatively look at the impact of religious identity on people's self-reported happiness in Bangladesh. Second, given that the analysis is anchored in Bangladesh our research offers an important contribution to a literature that is dominated by Western experiences and understandings of religion. Finally, the article contributes to the growing but still relatively thin literature on wellbeing and happiness in the Global South.

\section{Data, Methods and Descriptive Statistics}

Our analysis is rooted primarily in two main sources. First we examine quantitative data generated during the wellbeing in developing countries (WeD) programme carried out between 2002 and 2007. In particular, we focus on the programme's Resource and Needs Questionnaire (RANQ) which collected data on the demographic and socio-economic profile of 1500 households in six sites (250 households from each of the six different sites). The RANQ survey also collected information on religion and happiness levels of the household head which was reported on a scale of $1-3$, with $1=$ not too happy; $2=$ fairly happy; and 3 = very happy. Second, this core data analysis is supplemented by qualitative data gathered over an extended period covering 2008 till 2016. During this period, one of the authors (Devine) led an international research team looking specifically at the role of religion in wellbeing in Bangladesh. This was supported by subsequent interviews with key informants carried out repeatedly over a 6-year period.

\subsection{Introduction to the Sites}

In order to locate our analysis, we start with a brief overview of the empirical context of our research. Bangladesh is a relatively small country which has been transformed over the years by improved physical and informational connections. This has resulted in the expansion of urban centres and allowed for greater connectivity between rural locations and the urban centres which are effectively the hubs of economic, administrative, business 
Table 1 Introduction to the research sites

\begin{tabular}{|c|c|}
\hline Research site & Brief description \\
\hline Manikganj district & The district is $64 \mathrm{~km}$ from Dhaka the capital city \\
\hline Aloknagar (urban) site & $\begin{array}{l}\text { Aloknagar is situated at the centre of Manikganj, and is home to most of } \\
\text { the commercial and educational institutions, administrative and political } \\
\text { party offices. Aloknagar has relatively good services and amenities, con- } \\
\text { sists of wealthy residential areas and slums, and has a diverse population } \\
\text { in terms of religion and occupations. Aloknagar has been associated } \\
\text { with problems of drug addiction and fundamentalist protests in the past }\end{array}$ \\
\hline Bichittropur (closer rural site) & $\begin{array}{l}\text { Bichittropur is } 4.5 \mathrm{~km} \text { from Aloknagar, and communications are very } \\
\text { good. There are } 350 \text { households in the village with approximately } 77 \% \\
\text { Muslim and } 23 \% \text { Hindu households. The main occupations are agricul- } \\
\text { ture and business/trade. The village has electricity, core amenities and } \\
\text { schools }\end{array}$ \\
\hline Achingaon (remote rural site) & $\begin{array}{l}\text { Achingaon is } 18 \mathrm{~km} \text { from Aloknagar and has } 250 \text { households. All the } \\
\text { households are Muslim. Hindu households all migrated after Independ- } \\
\text { ence. The village is reliant on agriculture and some small, localised busi- } \\
\text { ness. There is a madrassah school, amenities are poor, the road unpaved } \\
\text { and there is no electricity }\end{array}$ \\
\hline Dinajpur district & The district is $415 \mathrm{~km}$ from Dhaka the capital city \\
\hline Baniknagar (urban site) & $\begin{array}{l}\text { Most of the commercial and educational institutions, administrative and } \\
\text { political party offices are situated in Baniknagar. There is a mixture of } \\
\text { wealthy settlements and slums, and a great deal of diversity in popula- } \\
\text { tion, religion and occupations. The centre has paved roads, electricity } \\
\text { facilities, schools, markets and a range of amenities }\end{array}$ \\
\hline Shantipur (closer rural site) & $\begin{array}{l}\text { Shantipur is } 5 \mathrm{~km} \text { from Dinajpur. The village has } 800 \text { households of which } \\
75 \% \text { are Muslim, } 22 \% \text { are Hindu and } 3 \% \text { are Santals. The main occupa- } \\
\text { tions are agriculture and small business/trade. The village has a school. } \\
\text { The majority of roads are paved, electricity is available }\end{array}$ \\
\hline Telkupigaon (remote rural site) & $\begin{array}{l}\text { Telkupigaon is } 15 \mathrm{~km} \text { from Dinajpur. The village has } 750 \text { households of } \\
\text { which } 75 \% \text { are Muslim and } 25 \% \text { are Hindu. Facilities are generally quite } \\
\text { poor; roads are only partly paved; there is a limited supply of electricity; } \\
\text { and the village has a small primary school but no local market }\end{array}$ \\
\hline
\end{tabular}

and political activity. In selecting research sites, we adopted a working hypothesis that proximity to urban centres impacted upon people's life chances and wellbeing aspirations. Thus those living in areas that are more remote from urban centres have less options than those living in areas that are closer to the urban centres. At the heart of this urban expansion is Dhaka, the country's capital city and one of the world's fastest growing cities. Thus in selecting sites, we first chose two Districts at different distances from Dhaka: Manikgang and Dinajpur, and within each District we then selected an urban site close to the municipal centre and two rural sites which again were at different distances from their respective urban centres. Table 1 offers a brief summary of the six sites.

\subsection{Methods}

In the RANQ data, global happiness is captured in the question "Taking all things together, how would you say things are these days? Would you say you are, very happy, fairly happy or not too happy".

The happiness equation takes the form of, 


$$
H_{i}=f\left(g\left(X_{i}\right)\right)+\varepsilon
$$

where self-reported happiness $\left(H_{i}\right)$ is a function of $g($.) that represents the individual's true level of life satisfaction (the latent variable that is not directly observed) determined by a vector of socio-economic variables $X_{i}$ and $\varepsilon$ is an error term. Following Blanchflower and Oswald (2004) the function $f($.) rises in two steps as $g$ increases. It is assumed that the true happiness level of the individual $g($.$) and thus the structure of this happiness is only known$ by the individual. The error term can be thought of as capturing the individual's inability to report his or her true level of happiness because of not knowing other people's reported happiness. The ordinal nature of the happiness question means an ordered probit model is used where life satisfaction takes three values ranging from 1 (not too happy these days), 2 (fairly happy these days) and 3 (very happy these days).

We situate religion amidst a standard set of determinants of happiness, constructed on the basis of our literature survey and the findings from our founding research projects in Bangladesh. The literature reports consistent findings across different cultures and countries, whether rich or poor. Thus, age has a U-shaped relationship with happiness and has been explained by the dynamics of changing expectations as well as a reduction in the gap between goals and achievements of individuals as they become older (Helliwell 2006). The significance of age in determining happiness was also confirmed in our previous research in Bangladesh (Camfield et al. 2009), and so we included the age and the age-squared of the household head in our analysis. As our data pertains to household heads only, the sample is biased towards people in the higher age bracket.

The literature is also consistent in reporting that healthier people and those who feel healthy report higher levels of happiness, a finding which was again confirmed in our earlier research in Bangladesh (Devine et al. 2008). We therefore created a variable of whether the head of the household suffers from chronic ill health to assess its impact on happiness. In our RANQ survey, $41 \%$ of respondents reported experiencing some sort of chronic illhealth condition. This high response level is consistent with data from Bangladesh confirming the prevalence of health related crisis and their negative impact on the socio-economic status of households (Khan et al. 2015).

In analysing RANQ data, we found significant differences between men and women in their reported levels of happiness as well as in the substantial content of what they valued as constituting happiness (Camfield et al. 2009). This contrasts with Asadullah and Chaudhury's (2012) study which found that gender had no impact on happiness in Bangladesh. In our sample, $92.9 \%$ of households are headed by males and $7.1 \%$ by women. In the context of Bangladesh, the latter implies a lack of 'male guardianship' and therefore greater exposure to disadvantage and oppression both within and beyond immediate communities.

Income levels tend to positively affect happiness although this relationship is contested. Easterlin's (1974) suggestion that rising societal incomes do not result in rising subjective wellbeing finds support in individual level studies reporting a concave relationship between income and happiness consistent with the law of diminishing returns (Clark and Qizilbash 2008). Issues of endogeneity arise in this line of reasoning however since happier people tend also to be more successful. In a recent review of Easterlin's apparent paradox, Diener et al. (2013) found that rising incomes are significantly associated with subjective well-being if they lead to more individual purchasing power, optimism and financial satisfaction. In arriving at this conclusion, the authors highlight three potential weaknesses in Easterlin's original argument: (a) he relied solely on GDP which does not reliably translate into increased household income; (b) he relied on data from a small and homogenous 
number of countries; (c) overall GDP growth may mask differences in the distribution of wealth.

Our RANQ data does not have information on household income or earnings partly because in Bangladesh they are not considered reliable indicators of wealth. Instead we have developed a wealth index proxy using principal component analysis. The index combines indicators including ownership of household consumer durables, physical living conditions, literacy status, food security, ownership of bicycle and motorbike; and the ownership of jewellery. We use a group of dummies instead of the asset index score because the distribution of the index was not normal and centred on certain values. Asset Index 4 is the highest category of assets. To capture relative wealth, we also calculate a series of dummy variables that are equal to 1 if household assets are greater than the average asset index for the site the household comes from. These dummies help capture wealth inequality at the local community level. The a priori here is that the relatively wealthy will report higher happiness, a finding confirmed by Asadullah and Chaudhury (2012).

Employment status also heavily dictates happiness with those unemployed being significantly less happy than the employed in both developed and developing countries (Clark and Oswald 1994; Kingdon and Knight 2004; Hinks and Gruen 2007). RANQ provides information on the occupations of household heads as well as whether searching or not searching for work, to capture the (in)voluntarily nature of being out of work.

Since we are exploring whether religion as a form of social identity is correlated with happiness, we expect this variable to pick up a range of unobservable factors such as economic discrimination, status and some elements of social capital such as friendships and strong social and personal networks, not sufficiently controlled for given our data limitation. Religious group is captured by a dummy variable that takes a value of 1 if Muslim and 0 if Hindu. Given the political economy of Muslim-Hindu relations in Bangladesh, we expect Muslims to be happier than Hindus because of both unobservable factors and the greater opportunities that arise from being a member of the majority group.

Our asset index and measure of relative wealth helps us control for any economic gains of belonging to the majority religion. The RANQ data allows us to test for social capital as represented by (1) connection to government and (2) connection to the local community. Putnam (2000) focussed on the impact social capital such as trust in others and belonging to a group or organisation had on the individual and on the local community. By controlling for political and social connections we can observe whether belonging to a particular religion and having these connections are capturing similar or identical social capital effects on life satisfaction. This is a sensible strategy since we can test whether being in a religious group is correlated with political connections something that is highly likely in a country where one religion dominates. If these are correlated then we can conclude that being a Muslim opens up connections that can be beneficial to the individual and to the group, but which is not open to Hindus and other minority religions.

In our RANQ sample, $18.7 \%$ of households claimed to have a connection to either local or national government. Of these the majority referred to connections with low government positions at village level $(6.5 \%)$, with just $0.9 \%$ relating to higher level positions. $1.4 \%$ of households claimed to have had a connection to high government positions in the past. Moreover, just 11.4\% of households reported being members of local groups, and the majority of these $(7.8 \%)$ refer to village based groups. In the vast majority of cases, this reflects membership of a Non-Governmental Organisation (NGOs) which in Bangladesh deliver core social services to millions of citizens throughout the country.

The literature reports a mostly positive association between location and wellbeing (Oswald and $\mathrm{Wu} 2009$ ). However the relationship is not always an obvious one. For 
Table 2 Levels of happiness across sites

\begin{tabular}{lllcllc}
\hline & $\begin{array}{l}\text { Not too } \\
\text { happy }=1\end{array}$ & $\begin{array}{l}\text { Fairly } \\
\text { happy }=2\end{array}$ & Very happy $=3$ & $\begin{array}{l}\text { Expected } \\
\text { happiness }\end{array}$ & \% Muslims & Observations \\
\hline Aloknagar & 6.44 & 77.25 & 16.31 & 2.10 & 0.639 & 233 \\
Bichittropur & 19.23 & 72.12 & 8.65 & 1.89 & 0.827 & 208 \\
Achingaon & 12.30 & 74.59 & 13.11 & 2.01 & 1.000 & 244 \\
Baniknagar & 15.77 & 58.92 & 25.31 & 2.10 & 0.905 & 241 \\
Shantipur & 31.65 & 60.76 & 7.59 & 1.76 & 0.878 & 237 \\
Telkupigaon & 27.50 & 66.25 & 6.25 & 1.79 & 0.829 & 240 \\
All sites & 18.82 & 68.21 & 12.97 & 1.94 & 0.848 & 1403 \\
\hline
\end{tabular}

Source: RANQ

example after controlling for several individual characteristics in their study, Ballas and Tramer (2012) report that 'people' and not 'place' determines happiness in the UK. If place has any impact, it is at a very localised and familiar level. This is a relevant finding for our study as local communities in Bangladesh are often the primary source of informal support for individuals and also the primary point of access to higher level organisations or institutions (Devine 2006). As our data was collected from six different sites, in our analysis we introduce site dummies using Shantipur as the reference site to account for the 'place' effects on wellbeing.

We regress happiness onto the variables that we have described. Formally this is represented by

$$
\begin{aligned}
H_{i}= & \beta_{1} \text { Assets }_{i}+\beta_{2} \text { Relative Assets }_{i}+\beta_{3} \text { Muslim }_{i}+\beta_{4} \text { Connection }_{i} \\
& +\sum_{j=1}^{n} \beta_{i j} X_{i j}+\sum_{m=1}^{6} \eta_{m} \text { Site }_{m}+\varepsilon_{i j}
\end{aligned}
$$

where the self-reported happiness $\left(H_{i}\right)$ of the head of household is determined by household assets $\left(\text { Assets }_{i} \text { ), relative household assets (Relative Assets }\right)_{i}$, whether a Muslim or not ( 1 if Muslim and 0 if Hindu), the household's political connectedness that is initially captured by a dummy variable ( Connection $_{i}$ ), that takes a value of 1 if someone has ever held or is currently holding a position in the local or national government and 0 otherwise, the site location $\left(\right.$ Site $\left._{m}\right)$ and $X_{i}$ is a vector of socio-economics characteristics (e.g. age, gender, health status, economic activity), $\varepsilon$ is an error term.

We do not claim causation from our estimations since we cannot control for unobservable individual and household heterogeneity and we interpret our results as correlations. ${ }^{2}$

\subsection{Descriptive Statistics}

Table 2 reports the overall levels of happiness across all six sites. Respondents from the two urban sites, Aloknagar and Baniknagar, are the happiest with expected happiness

\footnotetext{
2 The easiest way to solve this problem would be to use panel data that controls for changes in variables and relates to changes in happiness. Endogeneity issues also arise when using cross-sectional data. Our data is not a panel nor does it contain appropriate instrumental variables.
} 
scores of $2.10^{3}$ while 27.5 and $31.7 \%$ of respondents in our two most remote sites, Telkupigaon and Shantipur, are not too happy. This appears to confirm the hypothesis underpinning our site selection, i.e. that distance to urban centres impacts upon people's happiness. That there is little difference between respondents from Baniknagar and Aloknagar suggests that distance to Dhaka may not be significant. The most likely explanation here is that the construction of a $930 \mathrm{~m}$ bridge across the Meghna river has substantially improved communication and traffic between Dinajpur and Dhaka. As such, Baniknagar is now very well connected to the capital city.

The majority of our sample is male (92.9\%) and Muslim (84.8\%) and Muslims have higher average happiness levels than Hindus (see Table 3). Just under 1/5th of households had or still have a member with a position within local, regional or national government whilst $7.8 \%$ of households are members of some village based group. The relatively low share of households with assets greater than the site average indicates the highly skewed nature of assets within each of the sites and a high prevalence of wealth inequality.

\section{Results}

\subsection{Religion and Happiness}

It is clear from Table 4 that Muslims report significantly higher levels of happiness than Hindus. For ease of interpretation we only report ordered probit average marginal effects of being very happy using the post-estimation margins command in STATA. Compared to the average person in our sample Muslims in Model 1 are $6.8 \%$ more likely to be very happy compared to Hindus. This finding contrasts with Asadullah and Chaudhury's (2012) study, which found that religion was not correlated with wellbeing. In order to test whether greater happiness is the result of identity based on religious affiliation or the result of the relative status that religion generates within a community or nation, we interact being Muslim with the different sites to reveal whether there are differences in happiness depending on where Muslims live, ceteris paribus. Model 2 indicates that Muslims in Achingaon and Baniknagar are 14.8 and $15.3 \%$ more likely to be very happy relative to Hindus. Being Muslim in itself now does not significantly correlate with happiness. Instead given that Achingaon and Baniknagar have the highest proportion of Muslims in any of the six locations in our sample and given we control for absolute and relative wealth, age, subjective health, site and economic activity, our findings suggest that Muslims are significantly happier when residing in a site with many other Muslims. This has some important resonance with Eichhorn's (2012) findings that happiness through religiosity is not intrinsic but derived from the context in which people find themselves. In other words, people are not happier because they are individually more religious but because they live in a country, context or environment where other people are religious.

While Eichorn's conclusion is based on an analysis contrasting societies that are secular with others that are more religious, our research allows us to explore a context with a pattern of dominant and subordinate religious groups within the same society. The significance of being a member of a dominant or subordinate group is revealed in previous research by

\footnotetext{
${ }^{3}$ Expected happiness is calculated by multiplying the percentage of people in each of the categories by the happiness score.
} 
Table 3 Descriptive statistics of key happiness indicators

\begin{tabular}{|c|c|c|}
\hline Variable groups/names & Mean & SD \\
\hline Happiness: $1=$ not too happy, $2=$ fairly happy, $3=$ very happy & 1.942 & 0.561 \\
\hline \multicolumn{3}{|l|}{ Religious group } \\
\hline Muslim & 0.848 & 0.359 \\
\hline Hindu & 0.152 & 0.359 \\
\hline Mean happiness for Muslims & 1.951 & 0.557 \\
\hline Mean happiness for Hindus & 1.822 & 0.571 \\
\hline \multicolumn{3}{|l|}{ Personal characteristics of head of household } \\
\hline Age & 44.996 & 13.570 \\
\hline Age-squared & 2208.622 & 1365.266 \\
\hline Male & 0.929 & 0.257 \\
\hline Female & 0.071 & 0.257 \\
\hline Chronic ill health & 0.410 & 0.492 \\
\hline \multicolumn{3}{|l|}{ Household wealth } \\
\hline Asset Index 1 & 0.209 & 0.407 \\
\hline Asset Index 2 & 0.300 & 0.458 \\
\hline Asset Index 3 & 0.279 & 0.449 \\
\hline Asset Index 4 & 0.212 & 0.409 \\
\hline Assets greater than average asset in Aloknagar & 0.099 & 0.264 \\
\hline Assets greater than average asset in Bichittropur & 0.083 & 0.299 \\
\hline Assets greater than average asset in Achingaon & 0.076 & 0.286 \\
\hline Assets greater than average asset in Baniknagar & 0.090 & 0.250 \\
\hline Assets greater than average asset in Shantipur & 0.074 & 0.500 \\
\hline Assets greater than average asset in Telkupigaon & 0.067 & 0.262 \\
\hline \multicolumn{3}{|l|}{ Economic activity of head of household } \\
\hline Farmer & 0.166 & 0.372 \\
\hline Agricultural labourer & 0.085 & 0.279 \\
\hline Non-agricultural worker & 0.061 & 0.240 \\
\hline Transport worker & 0.090 & 0.286 \\
\hline Professional & 0.116 & 0.321 \\
\hline Home worker & 0.044 & 0.206 \\
\hline Artisan & 0.033 & 0.178 \\
\hline Commercial & 0.265 & 0.442 \\
\hline Other occupation & 0.069 & 0.254 \\
\hline Searching unemployed & 0.004 & 0.060 \\
\hline Non-searching unemployed & 0.010 & 0.099 \\
\hline Other non-labour activities (e.g. schooling) & 0.057 & 0.232 \\
\hline \multicolumn{3}{|l|}{ Social capital (1): government connections within the household } \\
\hline Someone in household has or holds a position in local or national government & 0.187 & 0.390 \\
\hline $\begin{array}{l}\text { Formal or informal village government position currently held by member of } \\
\text { the household (low-level) }\end{array}$ & 0.065 & 0.246 \\
\hline $\begin{array}{l}\text { Formal government position between local town and sub-district level currently } \\
\text { held by member of the household (middle-level) }\end{array}$ & 0.014 & 0.116 \\
\hline $\begin{array}{l}\text { Formal government position between district and national level currently held } \\
\text { by member of the household (high-level) }\end{array}$ & 0.009 & 0.092 \\
\hline
\end{tabular}


Table 3 (continued)

\begin{tabular}{llc}
\hline Variable groups/names & Mean & SD \\
\hline $\begin{array}{l}\text { Formal or informal village government position held between 1 and 30 years } \\
\quad \text { ago by member of the household (low-level) }\end{array}$ & 0.045 & 0.207 \\
$\begin{array}{l}\text { Formal government position between local town and sub-district level held } \\
\quad \text { between 1 and 30 years ago by member of the household (middle-level) }\end{array}$ & 0.041 & 0.199 \\
$\quad \begin{array}{l}\text { Formal government position between district and national level held between 1 } \\
\quad \text { and 30 years ago by member of the household (high-level) }\end{array}$ & 0.014 & 0.116 \\
Social capital (2): local connections & & \\
Member of village based groups & 0.078 & 0.269 \\
Member of externally organised government groups & 0.004 & 0.060 \\
Member of externally organised NGO & 0.032 & 0.176 \\
Geographic location & & \\
Aloknagar & 0.166 & 0.372 \\
Bichittropur & 0.148 & 0.355 \\
Achingaon & 0.174 & 0.379 \\
Baniknagar & 0.172 & 0.377 \\
Shantipur & 0.169 & 0.375 \\
Telkupigaon & 0.171 & 0.377 \\
Observations & 1403 & \\
\hline
\end{tabular}

Source: RANQ

Gupta et al. (2013) carried out in Bangladesh and West Bengal. Their research found that in both locations the minority groups (Hindus in Bangladesh and Muslims in West Bengal) exhibit significant in-group bias with respect to trustworthiness and the majority groups exhibit out-group bias. Furthermore minority groups in both locations show out-group discrimination in trust behaviour, indicating a fear of the power of the majority around them. Notwithstanding this, the authors argue that the minority groups are the beneficiaries in both countries given the lack of out-group discrimination of the majority and the in-group bias of the minority. This last conclusion is challenged by an earlier study looking at intergroup attributions and majority-minority group dynamics in Bangladesh (Islam and Hewstone 1993). The study examined the reaction of 58 Hindu and 59 Muslim students from the North West of the country to three short narratives describing a situation involving a Hindu or a Muslim actor behaving toward another subject in a positive or negative manner. They found in-group favouring among members of both minority and majority groups but especially in the latter. Moreover, they found "blatant out-group-derogating attributions" among members of the majority group (Islam and Hewstone 1993: 948).

\subsection{Socio-economic, Wealth, Economic Activity, Location and Happiness}

As found in previous cross-sectional work happiness is U-shaped in relation to age consistent with expectations and aspirations tending towards accepting your lot in life. ${ }^{4}$ Those

\footnotetext{
${ }^{4}$ More recent evidence from Frijters and Beatton (2012) using panel data finds no U-shaped relationship between age and life satisfaction because of a reverse causality issue. Variables that increase happiness such as being employed, income and getting married appear to happen mostly to middle-aged people who were already happy.
} 
Table 4 Determinants of happiness ordered probit average marginal effects

\begin{tabular}{|c|c|c|}
\hline Variables & (1) & (2) \\
\hline Muslim & $0.068 * * *$ & 0.053 \\
\hline Muslim * Bichitropur & & -0.057 \\
\hline Muslim * Alokenagar & & -0.029 \\
\hline Muslim * Achingaon & & $0.144 * * *$ \\
\hline Muslim * Baniknagar & & $0.152 * *$ \\
\hline Muslim * Telkupigaon & & 0.084 \\
\hline Alokenagar & 0.056 & 0.072 \\
\hline Bichitropur & 0.022 & 0.072 \\
\hline Achingaon & $0.142 * * *$ & $\mathrm{n} / \mathrm{a}^{\mathrm{a}}$ \\
\hline Baniknagar & 0.027 & -0.100 \\
\hline Telkupigaon & $0.051 *$ & -0.018 \\
\hline Age & $-0.006^{* *}$ & $-0.006^{* *}$ \\
\hline Age-squared & $0.000 * *$ & $0.000 * *$ \\
\hline Male & $0.068 *$ & $0.069 * *$ \\
\hline Chronic ill health & $-0.037 * * *$ & $-0.036^{* * *}$ \\
\hline Asset Index 1 & -0.050 & -0.051 \\
\hline Asset Index 2 & -0.039 & $-0.042 *$ \\
\hline Asset Index 4 & $0.095 * * *$ & $0.095 * * *$ \\
\hline Assets greater than average asset in Alokenagar & $0.100 * *$ & $0.093 * *$ \\
\hline Assets greater than average asset in Bichittropur & 0.023 & 0.027 \\
\hline Assets greater than average asset in Achingaon & 0.008 & 0.008 \\
\hline Assets greater than average asset in Baniknagar & $0.129 * * *$ & $0.118 * * *$ \\
\hline Assets greater than average asset in Shantipur & 0.046 & 0.044 \\
\hline Assets greater than average asset in Telkupigaon & 0.059 & 0.062 \\
\hline Farmer & $-0.068 * *$ & $-0.062 * *$ \\
\hline Agricultural labourer & $-0.151 * * *$ & $-0.145^{* * *}$ \\
\hline Non-agricultural worker & -0.001 & 0.013 \\
\hline Transport worker & $-0.064 * *$ & $-0.056^{*}$ \\
\hline Home worker & -0.014 & -0.003 \\
\hline Artisan & $-0.093 * *$ & -0.067 \\
\hline Commercial & -0.030 & -0.032 \\
\hline Other occupation & $-0.080 * * *$ & $-0.073 * *$ \\
\hline Searching unemployed & -0.045 & -0.028 \\
\hline Non-searching unemployed & $-0.147 * *$ & $-0.138 * *$ \\
\hline Other non-labour activities (e.g. schooling) & -0.023 & -0.019 \\
\hline Observations & 1403 & 1403 \\
\hline
\end{tabular}

Reference groups in Table 4 are female professionals residing in Shantipur who have level 2 assets Robust standard errors in parentheses $* * * p<0.01$; ** $p<0.05$; * $p<0.1$

a Achingaon sample is $100 \%$ Muslim

who are chronically ill are significantly less likely to report being very happy. Male heads are significantly more likely to be very happy compared to female heads. In the context of Bangladesh, with its strong patriarchal culture, women who have become household heads 
may have lower happiness level because of a lack of male representatives who can act as their guardians and voice in male dominated local communities, markets, bureaucracies, political bodies, and service providers such as hospitals and schools.

The wealthiest households (Asset Index 4) are 9.5\% more likely to report being very happy relative to the reference group (Asset Index 3) but those in the poorer categories are not significantly less happy. In contrast again to Asadullah and Chaudhury (2012), our findings suggest that relative wealth is more important than absolute wealth. We capture this relativity at the site level with the not unreasonable assumption that this is where wealth comparisons are more likely to be made. Households in the richest site of Baniknagar with above average wealth are $12.9 \%$ more likely to report being very happy compared to those with below average site wealth. In the least wealthy sites there is no significant difference in reported happiness between those above or below average wealth. This suggests that when a certain level of wealth is reached, the relative position of household wealth becomes important for happiness, even though this level is by international standards, still quite low. The site dummies indicate that there are significant differences in happiness levels between sites indicating unobservable characteristics.

Heads of households who are farmers, agricultural labourers, transport workers or artisans report significantly lower probabilities of being very happy relative to professional workers. These findings indicate that employment picks up other wellbeing dimensions besides income since we have controlled for absolute wealth. In Bangladesh employment is fundamentally associated with status and reputation. In our qualitative fieldwork we found across all sites that parents who had sent their children to school did not want them to be agricultural labourers since this was work for illiterate people (oshikkhitto). We also observed that educated young men preferred to remain unemployed than work on farms because they felt agricultural work would bring them and their families a bad reputation (durnam). These younger workers are prominent amongst the searching unemployed whose happiness is not significantly different from that of professional workers. The nonsearching unemployed however are $14.7 \%$ less likely to report being very happy.

\subsection{Qualitative Evidence of Religion and Happiness}

Above we argued that Muslims reported higher levels of happiness than Hindus but that happiness correlates more with Muslims residing in sites with other Muslims (group membership) rather than with simply being Muslim (religious affiliation). As indicated earlier, the word for religion in Bangladesh (dharma) picks up on religious affiliation but also on how affiliation interacts with other cultural, social and political dynamics. The two dimensions of religion are inseparable, and this we argue, helps shed light on discussions about religious affiliation and majority/minority group dynamics. Below we summarise two cases from two of our research sites, which offer insights into both dimensions of dharma.

In Shantipur there is a large Muslim majority (75\%) and a significant Hindu minority $(22 \%)$. In recounting the history of the community, respondents across the religious spectrum told us that until the time of Liberation (1971) most of the Hindu families were landowners, with some owning large plots of agricultural land. Today instead all the Hindu households are functionally landless, having had their lands taken off them by force, and now reside in the geographically less favourable land of the village. Their sense of fear is lived out in everyday experiences of discrimination and exploitation: they get paid less than other day labourers; they are often not paid on time; they are blamed for trouble in 
the village; they are ordered to carry out demeaning work like cleaning latrines; they are prevented from practising their religion; they are routinely accused of drinking alcohol and having illicit sexual relations. They are also routinely excluded from accessing core welfare services. During our time in the village for example, not a single member of a Hindu household was in receipt of any of the social protection benefits distributed by government despite the fact that the Hindus were clearly among the poorest in the village. In an interview with a local government official, one of the authors (Devine) asked why Hindus were never on the list of those to receive government welfare support. The official's response was that it made less sense to give resources to Hindus because they all wanted to escape to India anyway. In his words: "government helps all citizens but they (Hindus) are always looking over the border. They are not real citizens. They do not love this country". Meanwhile in the village, one Hindu reflected on the precariousness of their position: "It is good that we have some Santals in our community", he said, "it means someone else shares our bad fortune". 5

In Achingaon there are no religious minority groups. The Hindus all left around Independence in 1971. Residents of Achingaon commonly report that their community is peaceful and older residents in particular recall less harmonious times when Hindus resided in the village. This narrative of peace and harmony however sat cumbersomely with our observations of tension and division in Achingaon, caused by intense and occasionally violent break-ups of traditional community groups into smaller factions (Devine and White 2013). Indeed of all our research sites, Achingaon was the least peaceful. Although the village has around 250 households and is therefore relatively small, it has a total of eight mosques all served by a different imam (Islamic worship leader). Each mosque represents a samaj or community within the village. As little as two generations ago, there were four samajes in the village and now the number has grown to nine with the most recent one trying to build its own mosque. Since the departure of the Hindus, the pace with which new samajes have been created, has increased. The creation of a new samaj is inevitably triggered by power struggles within the village. We observed the embryonic stages of the creation of the ninth samaj (Devine and White 2013). The case is typical and demonstrates a pattern in which emerging leaders within an existing samaj become rivals to the existing leadership, and then need to convince enough people to break away and join them in a separate samaj. In the case of the ninth samaj, the traditional leader owned large plots of land and gave labouring jobs to samaj members in return for their loyalty. However the leader was accused by younger rivals of not caring enough for the samaj members. On the basis of their connections with external political or business leaders with access to resources and goods, these younger rivals began to offer access to services as a means of building up an alternative power base in the village. Villagers were forced to decide whether to invest their loyalties in the traditional leader who offered seasonal employment but with diminishing economic and political resources, and emerging leaders with access to those with more financial power and political clout. As a result, samaj allegiances broke up with neighbour pitted against neighbour, relative against relative, brother against brother. The increased fragmentation of the community was widely seen as a negative development by community members in that it created divisions, caused tension and was described to us as 'going against our religion' (dharma). The legitimacy of the ninth samaj depended on building a mosque since this signalled a place of unity and support, separate from the other unities in

5 The Santals are one of the largest indigenous communities in the Northwest of Bangladesh. 
the village. One elderly member of the ninth samaj told us: "we don't pray in the mosques of the other samajes. We go outside. Members of mosques help each other but don't help outsiders. They don't want us in their mosques. What matters here is being in the most powerful group, then you are always right. If you are in the weakest group, you are left out".

What lessons can we draw from the two cases? On the one hand, the case of Shantipur demonstrates how Hindus face constant discrimination and oppression, and how their life chances are constrained on account of their religious affiliation. This is consistent with reports from elsewhere in Bangladesh highlighting the levels of vulnerability, marginalisation and violence faced by religious minority or subordinated groups (Benkin 2015). In Shantipur, our case demonstrates that religious affiliation has come to reinforce boundaries that legitimise and sharpen relations of inequality. Those boundaries are marked by social, political and economic exclusion and discrimination. Ironically, the observations about Shantipur are mirrored in Achingaon where there are no religious minorities. Here again we observe internal struggles, marked by religious symbols and boundaries notably in mosque construction, membership and participation but also in choices around who to help and support within the village. Membership of majority groups in both sites are related to power dynamics which directly impact upon wellbeing opportunities. This highlights the significance of relations and connectedness for wellbeing and happiness.

\subsection{Robustness Checks}

In line with understanding whether social capital, measured here by political connectedness and membership of groups, can partly explain why Muslims are happier than Hindus we run Model 1 again and include a number of different measures of being politically connected. We initially capture political connectedness by a composite term that considers whether individuals have had or still have a family member with a role in local or national government. Table 5, Model I shows that political connectedness correlates with higher levels of happiness, and that those with such connections are $4.2 \%$ more likely to report being very happy than those without the same connections. We observe too that Muslims remain significantly happier than Hindus although the size of coefficient declines slightly. We interpret this as meaning being a Muslim in and of itself correlates with greater happiness and that there is little evidence that being a Muslim and being politically connected are capturing the effects of similar or identical social capital on happiness. When we control for individual parts of the composite variable in Model II, there is evidence that marginal effects increase depending on whether government connections are at a low, middle or high level though only two categories are statistically significant ${ }^{6}$ and the coefficient for Muslims does not significantly change. These two statistically significant categories underline the significance of having connections with someone who has held a formal political position as opposed to an informal position. Moreover it is interesting to note that the statistically significant political connection today is located between district and national

\footnotetext{
6 The results do not change significantly when we include the Muslim * site interactions terms from Model II in Table 4. It is also likely that the heads of households who are responding to these questions are themselves those who are connected. Some of the characteristics of having a formal position in local, sub-district, district and national government will be captured by the group of economically active dummies included as controls in Table 5. So any politically connected variables that are significant indicate effects on happiness external to the job itself, e.g. status.
} 
levels. This reflects broader political economy changes in Bangladesh which has seen power move progressively away from local village based elites to actors with connections to central or national political bodies-a shift that was reflected very well in the emergence of the ninth samaj in Achingaon.

When we include membership of different groups in the model we find that membership of non-governmental groups (NGOs) is associated with higher happiness scores with no impact on Muslims being happier than Hindus, and that this result is robust when including political connections (Model IV). This is entirely consistent with our analysis of the significance of externally facing connections. Unlike local village based organisations that are formed around kinship ties and loyalties and involve low level reciprocal exchanges, NGOs provide access to external resources and services; support the development of higher level reciprocal exchanges; and also open up connections between NGO members and formal government officials and offices.

A further robustness check is to test whether our results in Table 5 are nationally representative by estimating happiness equations for each of the six sites. The results are reported in Table 6.

Being Muslim in Baniknagar and Telkupigaon correlates with a greater likelihood of being very happy. Whilst 91 and $83 \%$ of the samples in Baniknagar and Telkupigaon are Muslims respectively, that we do not find similar results in Bichittropur and Shantipur indicates the need for caution in saying Muslims are happier when living in high density Muslim locations. In four of the six sites having a family member who is a member of an NGO significantly increases the likelihood of being 'very happy'. Only in the most remote and rural site of Telkupigaon is membership of a village organisation economically and significantly correlated with happiness. It is not surprising that the most remote site of our six locations is the one where village based organisations may be significant as it is likely to be the site that is most disconnected from the social, economic and political centres of power. When there are few or no options to access these external centres, local connections matter much more. Table 6 also highlights that direct government connections are only economically and statistically important for happiness in Aloknagar, the most urban of our six sites and the closest to Dhaka the capital city and that Muslims are not significantly happier than Hindus in this site. When we run the model without direct government connections the finding of no impact of religion on happiness holds, indicating that being a Muslim and being politically connected are not correlated.

\section{Conclusion}

This paper contributes to the literature on the determinants of happiness, and the extent and ways in which religion affects happiness in the global south. Whilst research on religion and happiness has tended to focus on individual-level aspects of wellbeing, reflecting mostly Western experiences and understandings of religion, our argument highlights more explicit structural explanations of the ways religion articulates individual happiness in Bangladesh. Our analysis suggests religion matters to wellbeing because it influences the everyday social and political processes that determine people's life chances. Incorporating a more contextualised analysis in this way highlights the importance of specific processes and mechanisms that give shape to the way religion is articulated, and to the way people then experience and assess it (Eichhorn 2012). 
Table 5 Political connectedness and happiness ordered probit average marginal effects

\begin{tabular}{|c|c|c|c|c|}
\hline Variables & (I) & (II) & (III) & (IV) \\
\hline Muslim & $0.061 * * *$ & $0.062 * * *$ & $0.068 * * *$ & $0.061 * * *$ \\
\hline $\begin{array}{l}\text { Someone in household has or does hold a position in local } \\
\text { or national government }\end{array}$ & $0.042 * * *$ & & & \\
\hline $\begin{array}{l}\text { Formal or informal village government position currently } \\
\text { held by member of the household (low-level) }\end{array}$ & & 0.035 & & 0.036 \\
\hline $\begin{array}{l}\text { Formal government position between local town and sub- } \\
\text { district level currently held by member of the household } \\
\text { (middle-level) }\end{array}$ & & -0.014 & & -0.008 \\
\hline $\begin{array}{l}\text { Formal government position between district and national } \\
\text { level currently held by member of the household (high- } \\
\text { level) }\end{array}$ & & $0.117 *$ & & $0.126^{*}$ \\
\hline $\begin{array}{l}\text { Formal or informal village government position held } \\
\text { between } 1 \text { and } 30 \text { years ago by member of the household } \\
\text { (low-level) }\end{array}$ & & 0.031 & & 0.033 \\
\hline $\begin{array}{l}\text { Formal government position between local town and } \\
\text { sub-district level held between } 1 \text { and } 30 \text { years ago by } \\
\text { member of the household (middle-level) }\end{array}$ & & $0.054 *$ & & $0.052 *$ \\
\hline $\begin{array}{l}\text { Formal government position between district and national } \\
\text { level held between } 1 \text { and } 30 \text { years ago by member of the } \\
\text { household (high-level) }\end{array}$ & & 0.085 & & 0.071 \\
\hline Member of village based groups & & & 0.012 & 0.009 \\
\hline Member of externally organised government groups & & & 0.044 & 0.056 \\
\hline Member of externally organised non-governmental groups & & & $0.096 * *$ & $0.094 * * *$ \\
\hline Personal characteristics & Yes & Yes & Yes & Yes \\
\hline Site & Yes & Yes & Yes & Yes \\
\hline Assets & Yes & Yes & Yes & Yes \\
\hline Relative assets & Yes & Yes & Yes & Yes \\
\hline Economic activity & Yes & Yes & Yes & Yes \\
\hline Observations & 1403 & 1403 & 1403 & 1403 \\
\hline
\end{tabular}

Reference groups in the Table 4 are female professionals residing in Shantipur who have level 2 assets

Robust standard errors in parentheses $* * * p<0.01$; ** $p<0.05 ; * p<0.1$

Amongst standard determinants of happiness, we found proximity to major urban centres is associated with higher levels of happiness; age has a U-shaped relation with happiness as people adjust their aspirations with age and experience; and self-reported chronic illness significantly lowers happiness. Heads of households with manual or agricultural jobs report significantly lower happiness scores than professionals, even after controlling for absolute wealth. Employment categories seem to capture income effects and are likely to be associated with social status in Bangladesh. Wealth matters in explaining happiness. The wealthiest are 9.5 percentage points more likely to report being very happy compared to the reference group. However, relative wealth at the community level is more important that absolute wealth. This is particularly the case in the richest sites where those with above average wealth are significantly more likely to report being very happy compared to those with below average wealth. Nonetheless in the least wealthy site, the difference between the wealthiest and poorest seems to matter less suggesting inequality becomes significant after a certain level of wealth. Finally, we found that male household heads report 
Table 6 Ordered Probit Happiness Equations by Site (Average marginal effects of being Very Happy)

\begin{tabular}{ll}
\hline Variables & $\begin{array}{l}\text { Marginal effect of } \\
\text { being very happy }\end{array}$
\end{tabular}

Bichittropur $(n=208)$

Muslim

Government contact

Member of village based groups

Member of externally organised government groups

0.007

Member of externally organised non-governmental groups

$0.124 * *$

\begin{tabular}{lrr}
\hline & Model 1 & Model 2 \\
\hline Aloknagar $(n=233)$ & & 0.026 \\
Muslim & $0.122^{* *}$ & -0.079 \\
Government contact & -0.083 & 0.076 \\
Member of village based groups & 0.107 & $0.121^{*}$ \\
Member of externally organised government groups & $0.130^{*}$ & Marginal effect of \\
Member of externally organised non-governmental groups & & being very happy
\end{tabular}

Achingaon $^{a}(n=244)$

Muslim

$\mathrm{n} / \mathrm{a}$

Government contact

0.000

Member of village based groups

0.013

Member of externally organised government groups

$\mathrm{n} / \mathrm{a}$

Member of externally organised non-governmental groups

0.138

Baniknagar $(n=241)$

Muslim

Government contact

Member of village based groups

0.105

Member of externally organised government groups

0.093

Member of externally organised non-governmental groups

Telkupigaon $(n=240)$

Muslim

Government contact

Member of village based groups

$0.113 *$

Member of externally organised government groups

$-0.009$

Member of externally organised non-governmental groups

Shantipur $(n=237)$

Muslim

Government contact

0.040

Member of village based groups

$-0.022$

Member of externally organised government groups

$-0.076$

Member of externally organised non-governmental groups

0.038

Reference groups in the Table 6 are female professionals who have level 2 assets. We control for absolute asset level, relative asset level within each site, age, gender, chronic health and economic activity

Robust standard errors in parentheses $* * * p<0.01 ; * * p<0.05 ; * p<0.1$

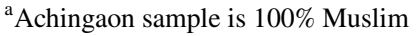


higher levels of happiness that females. Building on our qualitative work, we argue that the differences between males and females reflect the strength of patriarchy in influencing livelihood options and wellbeing aspirations. However it is important to note that our survey questionnaire gathers information on household heads and not all members of the household. As such, females are underrepresented in our data and those that are included are certainly not representative of the population of Bangladeshi women. This limitation in our data points to a need for further research into how religion figures in the happiness of women in Bangladesh.

Our key finding is that religious identity is a significant determinant of happiness in Bangladesh even after controlling for other variables of age, health, location, occupation, absolute and relative wealth and economic activity. Muslim household heads report significantly higher levels of happiness than Hindus. Importantly, levels of happiness of Muslims are significantly higher in sites with the highest proportion of Muslims population. These are important findings that extend Eichhorn's (2012) invitation to investigate links between religion and happiness in different groups or denominations within society, and assess the impact of the differences on happiness. Our analysis of both Muslim and Hindu respondents supports the argument that happiness through religiosity is not derived from religion per se but from belonging to the dominant or subordinate group. This membership is crucial to both out-group and in-group relational dynamics and trust. This relational and very practical aspect lies at the heart of an understanding of religion as dharma.

Social relationships matter when considering wellbeing in Bangladesh. We found higher reported levels of happiness among those with a family member having a role in government especially if the connection is to someone in central government as opposed to local government; among those with connections with someone who used to work for government; and among those with connections to NGOs via membership. These connections and relations highlight the ongoing but changing significance of the political economy of access to resources and life enhancing opportunities in Bangladesh. This political economy sits firmly on an in-group/out-group dynamic which can not be separated from the everyday experience of dharma.

Acknowledgements The data used in the article was gathered over three research phases: (a) the Wellbeing in Developing Countries programme (2002-2007) funded by the UK's Economic Social Research Council. Reference: M569255001; (b) the Religion and Development programme (2008-2010) funded by the UK's Department for International Development. Reference P/O 4000984; (c) unfunded research carried out by Devine. The authors acknowledge the support of the ESRC and DFID.

\section{Compliance with Ethical Standards}

Conflict of interest The authors declare that they have no conflict of interest.

Open Access This article is distributed under the terms of the Creative Commons Attribution 4.0 International License (http://creativecommons.org/licenses/by/4.0/), which permits unrestricted use, distribution, and reproduction in any medium, provided you give appropriate credit to the original author(s) and the source, provide a link to the Creative Commons license, and indicate if changes were made.

\section{References}

Allport, G. W., \& Ross, J. M. (1967). Personal religious orientation and prejudice. Journal of Personality and Social Psychology, 5, 432-443. 
Asadullah, M. N., \& Chaudhury, N. (2012). Subjective well-being and relative poverty in rural Bangladesh. Journal of Economic Psychology, 33(5), 940-950.

Ballas, D., \& Tramer, M. (2012). Happy people or happy places? A multilevel modeling approach to the analysis of happiness and well-being. International Regional Science Review, 35(1), 70-102.

Basu, I., Brown, G., \& Devine, J. (2017). Governance, rights and the demand for democracy: Evidence from Bangladesh. In I. Basu, J. Devine, G. D. Wood, \& R. Khair (Eds.), Politics and governance in Bangladesh: Uncertain landscapes. London: Routledge.

Benkin, R. (2015). Ethnic cleansing. The neglected case of Hindus of Bangladesh. In S. Kukreja (Ed.), State, society and minorities in South and South East Asia (pp. 63-86). Lanham, MD: Lexington Books.

Blanchflower, D. G., \& Oswald, A. J. (2004). Well-being over time in Britain and the USA. Journal of Public Economics, 88, 1359-1386.

Camfield, L., Choudhury, K., \& Devine, J. (2009). Well-being, happiness and why relationships matter: Evidence from Bangladesh. Journal of Happiness Studies, 10, 71-91.

Clark, D. A. (Ed.). (2012). Adaptation, poverty and development: The dynamics of subjective well-being. London: Palgrave Macmillan.

Clark, E. A., \& Oswald, A. (1994). Unhappiness and unemployment. Economic Journal, 104, 648-659.

Clark, D. A., \& Qizilbash, M. (2008). Core poverty, vagueness and adaptation: A new methodology and some results for South Africa. Journal of Development Studies, 44(4), 519-544.

Devine, J. (2006). NGOs, politics and grassroots mobilisation: evidence from Bangladesh. Journal of South Asian Development, 1(1), 77-101.

Devine, J., Camfield, L., \& Gough, I. (2008). Autonomy or dependence - or both?: Perspectives from Bangladesh. Journal of Happiness Studies, 9, 105-138.

Devine, J. \& White, S. C. (2013). Religion, politics and the everyday moral order in Bangladesh. Journal of Contemporary Asia, 43(1), 127-147.

Devine, J., \& Wood, G. D. (2017). Leaving no-one behind in Bangladesh: the case for a new political settlement. In Devine, J., Ali, Z., Wood, G. D., \& Shamsul, A. (Eds.), Extreme Poverty, Growth and Inequality in Bangladesh (pp.31-51). Rugby: Practical Action Publishing.

Diener, E., Tay, L., \& Oishi, S. (2013). Rising income and the subjective well-being of nations. Journal of Personality and Social Psychology, 4(2), 267-276.

Easterlin, R. (1974). Does economic growth improve the human lot? In P. David \& M. Reder (Eds.), Nations and households in economic growth: Essays in honor of Moses Abramovitz (pp. 89-125). New York, NY: Academic Press.

Eichhorn, J. (2012). Happiness for believers? Contextualizing the effects of religiosity on life-satisfaction. European Sociological Review, 28, 583-593.

Elliot, M. (2014). Thai Buddhism and well-being: An application of stress process theory. Mental Health, Religion and Culture, 17(9), 923-936.

Ellis, A. (1962). Reason and emotion in psychotherapy. New York, NY: Lyle Stuart.

Ellison, C. G., Gay, D. A., \& Glass, T. A. (1989). Does Religious commitment contribute to individual life satisfaction? Social Forces, 68, 00-123.

Frijters, P., \& Beatton, T. (2012). The mystery of the U-shaped relationship between happiness and age. Journal of Economic Behavior and Organization, 82(2-3), 525-542.

Ganga, N., \& Kutty, V. (2013). Influence of religion, religiosity and spirituality on positive mental health of young people. Mental Health, Religion and Culture, 16(4), 435-443.

Greeley, A., \& Hout, M. (2006). The truth about conservative Christians: What they think and what they believe. Chicago, IL: University of Chicago Press.

Gupta, G., Mahmud, M. Maitra, P., Mitra, S., \& Neelim, A. (2013). Religion, minority status and trust: Evidence from a field experiment. Monash University, Department of Economics discussion paper 28/13. Last accessed December 1, 2015.

Helliwell, J. F. (2006). Well-being, social capital and public policy: What's new? Economic Journal, $116(510), \mathrm{C} 34-\mathrm{C} 45$.

Hinks, T., \& Gruen, C. (2007). What is the structure of South African happiness equations? Evidence from quality of life surveys. Social Indicators Research, 82(2), 311-336.

Inden, R. (1985). Lordship and caste in Hindu discourse. In R. Burghartand \& A. Cantlie (Eds.), Indian religion (pp. 159-177). London: Curzon Press.

Islam, R., \& Hewstone, M. (1993). Dimensions of contact as predictors of intergroup anxiety, perceived out-group variability, and out-group attitude: An integrative model. Personality and Social Psychology Bulletin, 19, 700-710.

Joshanloo, M. (2013). A comparison of Western and Islamic conceptions of happiness. Journal of Happiness Studies, 14(6), 1857-1874. 
Joshanloo, M. (2014). Eastern conceptualizations of happiness: Fundamental differences with western views. Journal of Happiness Studies, 15(2), 475-493.

Khan, J., Trujillo, A., Ahmed, S., Siddiquee, A., Alam, N., Mirelman, A., et al. (2015). Distribution of chronic disease mortality and deterioration in household socioeconomic status in rural Bangladesh: An analysis over a 24-year period. International Journal of Epidemiology, 44(6), 1917-1926.

Kingdon, G., \& Knight, J. (2004). Unemployment in South Africa: The nature of the Beast. World Development, 32(3), 391-408.

Kotalova, J. (1993). Belonging to others, cultural; construction of womanhood among Muslims in a village in Bangladesh. Sweden: Uppsala University.

Lavrič, M., \& Flere, S. (2007). Intrinsic religious orientation and religious rewards: An empirical evaluation of two approaches to religious motivation. Rationality and Society., 23, 217-233.

Levin, J. (2014). Religion and happiness among Israeli Jews: Findings from the ISSP religion III survey. Journal of Happiness Studies, 15(3), 593-611.

Lim, C., \& Putnam, R. D. (2010). Religion, social networks, and life satisfaction. American Sociological Review, 75(6), 914-933.

Luttmer, E. (2005). Neighbors as negatives: Relative earnings and well-being. Quarterly Journal of Economics, 120, 963-1002.

Mahony, W. (1987). Dharma. In M. Eliade (Ed.), The encyclopaedia of Religion (Vol. 4, pp. 329-332). London: Collier Macmillan.

Mookerjee, R., \& Beron, K. (2005). Gender, religion and happiness. The Journal of Socio-Economics, 34(5), 674-685.

Oswald, J., \& Wu, S. (2009). Wellbeing across America. IZA discussion paper 4600. Last accessed December $1,2015$.

Putnam, R. D. (2000). Bowling alone. The collapse and revival of American community. New York, NY: Simon and Schuster.

Riaz, A. (2004). God willing: The politics of Islamism in Bangladesh. New York, NY: Rowman and Littlefield.

Sahraian, A., Gholami, A., Javadpour, A., \& Omidvar, B. (2013). Association between religiosity and happiness among a group of Muslim undergraduate students. Journal of Religion and Health, 52(2), $450-453$.

Shams, K. (2016). Developments in the measurement of subjective well-being and poverty: An economic perspective. Journal of Happiness Studies, 17, 2213-2236.

Steiner, L., Leinart, L., \& Bruno, F. (2010). Economics, religion and happiness. Zeitschrift für Wirtschaftsund Unternehmensethik, 11(1), 9-24.

Uddin, S. M. (2006). Constructing Bangladesh: Religion, ethnicity, and language in an Islamic Nation. Chapel Hill, NC: University of North Carolina Press.

White, S. C. (2012). Beyond the paradox: Religion, family and modernity in contemporary Bangladesh. Modern Asian Studies, 46(5), 1429-1458.

Witter, R., Stock, W., Okun, M., \& Haring, M. (1985). Religion and subjective well-being in adulthood: A quantitative synthesis. Review of Religious Research, 26, 332-342.

Worcester, R. M. (1998). More than Money. In I. Christie \& L. Nash (Eds.), The good life. London: Demos. 